\title{
SOSYAL MEDYADA OTOSANSÜR: FACEBOOK ÖRNEĞi ${ }^{1}$
}

Duygu TOSUNAY ${ }^{2}$

Figen ÜNAL ÇOLAK ${ }^{3}$

\begin{abstract}
öz
Herkesçe kabul edildiği gibi İnternet, iletişimin geçmişe göre daha kolay gerçekleşmesine yardımc1 olmaktadır. Dünyanın küçüldüğü algısını da beraberinde getiren bu görüş, bu küçük dünya içindeki etkileşimlerin daha hızlı ve etkin biçimde gerçekleşmesine yaramaktadır. Bu açıdan bakıldığında, sosyal medya kavramı da bireylerin etkileşim hızına katkı sağlayan bir olgu olarak dikkat çekmektedir. Ancak iletişimin başatlığına paralel olarak ilerleyen denetim kavramı da, İnternet ve sosyal medyanın gelişimine ayak uydurmayı başarmış; farklı yollarla İnternet'in sunduğu özgürlük alanının sınırlanması yolunda kimi adımlar atmıştır. Sansür kavramının karşılayabileceği sınırlamalar, bariz denebilecek biçimlerde İnternet ve sosyal medyanın yarattığı hareketlenmeler dâhilinde de görünür olmuşlardır. Sansürün doğal bir sonucu olarak görülebilecek otosansür de bireylerin sosyal medyadaki etkileşimleri üzerinde söz sahibi olma potansiyeli nedeniyle günümüz İnternet dünyası içinde önemli bir yer teşkil etmeye başlamıştır. Bu çalışma da Facebook örneği üzerinden sosyal medyadaki otosansür eğilimlerini ortaya koymayı amaçlamaktadır. Bu çalışma, gözetim ve suskunluk sarmalı bağlamında, çevrimiçi anket ve yarı yapılandırılmış görüşme aracılığıyla Facebook kullanıcılarının davranışlarını inceleyerek otosansür davranışlarını ortaya koymayı amaçlamaktadır.
\end{abstract}

Anahtar Kelimeler: Otosansür, İnternet sansürü, suskunluk sarmal1, gözetim, Facebook

\section{SELF-CENSORSHIP IN SOCIAL MEDIA: FACEBOOK SAMPLE}

\section{ABSTRACT}

It is a well-established fact that the İnternet makes communicating easier comparing to the past. This idea, coming along with the perception of the world getting smaller, helps make the interactions more rapid and more efficient. From this point of view, the term social media emerges as an important concept which helps the interaction speed among the individuals. However control, as a defining concept which walks hand-in-hand with communication, has been keeping up with the İnternet and social media, also created various ways of limiting the freedom İnternet itself has provided. Limitations which can be described within censorship became apparent in the field of the movement which İnternet and social media has created. Self-censorship, which can be seen as a natural result of censorship itself, gained importance and has been holding a significant role due to its potential of limiting the interactions of the individuals. This study aims to reveal the self-censorship acts on social media through Facebook. This study aims to analyze the behaviours of Facebook users, in the context of surveillance and spiral of silence via using an online survey and semi structured inteview.

Keywords: Self-censorship, internet censorship, spiral of silence, surveillance, Facebook

\footnotetext{
${ }^{1} \mathrm{Bu}$ çalışma, 2015 yılında Anadolu Üniversitesi Sosyal Bilimler Enstitüsü İletişim Tasarımı ve Yönetimi Anabilim Dalı'nda tamamlanan aynı isimli yüksek lisans tezinin özetidir.

${ }^{2}$ Araş. Gör. Anadolu Üniversitesi İletişim Bilimleri Fakültesi, dtosunay@ anadolu.edu.tr

${ }^{3}$ Doç. Dr. Anadolu Üniversitesi İletişim Bilimleri Fakültesi, fiunal@anadolu.edu.tr
} 


\section{Giriş}

İnternet ve sosyal medya, bireyin temel iletişim alışkanlıklarıyla birlikte gündelik yaşamı da şekillendiren bir yapı halini almıştır. Web 2.0 ile birlikte bireyin İnternet'te etkin bir rol almasıyla birlikte ifade özgürlüğü konusu da farklı bir yönde şekillenmeye başlamıştır. Herkesin eşit sayılabilecek şansta söz söyleme hakkı olan bir ortamda bireyin özgürlügünü engelleyen her türlü faktör, etkilediği alan açısından geleneksel medyaya göre çok daha büyük bir etkiye sahiptir. Bu yüzden sosyal medyadaki otosansürün son yıllardaki iletişim süreçlerine olan etkisi çok büyüktür.

\section{Alanyazın}

\subsection{Internet sansürü ve otosansür}

Günümüzde oldukça hissedilen bir baskı aracı haline gelen İnternet sansürünün, yoğun olarak 2007 yılında başladığı kabul edilmektedir. 2007 yılının özelliği, 5651 sayılı kanunun kabul edilmesidir. Ancak 2007 yılından önce herhangi bir sansür eyleminin olmadığını söylemek doğru değildir. "Herkes İnternet sansürünü 2007'den başlatma eğilimindedir. Oysa 2001-2006 yılları İnternet sansürünün yükseliş dönemidir. 2000 ile 2007 yılları arasında, sanıldığının aksine, birçok site engelleme olayı yaşamıştır (Uçkan, 2009)”. Site kapatma girişimleri 2007 yılına kadar servis sağlayıcılar üzerinden gerçekleştirilirken, 5651 sayılı kanunun ortaya çıkmasıyla birlikte bu kanunun gerektirdiği farklı uygulamalar da tartışılmaya başlanmıştır. 5651 sayılı kanunun ortaya çıkışı, İnternet'te suç teşkil eden hareketlerin kontrolüyle ilgili yaşanan tartışmaların bir sonucudur.

“Türkiye'de Telekomünikasyon İletişim Başkanlığı'nın (TİB) fiilen çalışmaya başladığı 23 Kasım 2007 tarihinden 19 Ocak 2009 tarihine kadar geçen sürede kuruma resmi rakamlarla 42.207 adet ihbar gelmiş ve toplam 1.209 adet site erişime kapatılmıştır (Şen 2009'dan Akt., Köse ve Özen, 2010: 117)”. Bu durum, söz konusu denetimin kontrolsüz bir sansür ortamı yarattı̆̆1 şüphesiyle tartışma yaratmıştır. Söz konusu yetkinin sınırlarının tam olarak anlaşılamaması ve erişilebilen verilerin limitinin belirsizliği tepki çekmiştir. $\mathrm{Bu}$ da İnternet'in, insanların davranışlarına müdahale edilebilen yeni bir kamusal alan olarak ortaya çıkmasının bir sonucu olarak değerlendirilmiştir. 
Sansürün yaygınlaşmasıyla birlikte normalleşmesi süreci, insanların otosansür aracılığıyla sansürü desteklemelerine yol açan bir duruma dönüştürmektedir. Dolayısıyla otosansürün olduğu yerde sansürün varlığını aramak yanlış olmayacaktır. Otosansürü kişinin kendi sansürü olarak değil, ortaya çıkışındaki sebepleri inceleyerek tanımlamak daha doğru olacaktır. Cook ve Heimann (2010) otosansürün ortaya çıkışında kişiden bağımsız bir sansür faktörünün varlığını tartışmaktadırlar. Onlara göre kamusal ve özel olarak sınıflandırılabilecek iki otosansür türü vardır. Kamusal otosansürde birey kamusal olarak uygulanan bir sansürün etkisiyle otosansür uygularken, özel otosansürde bireyin kendi iç iletişimini etkileyen faktörler söz konusudur. "Bir davranışın otosansür olarak değerlendirilebilmesi için, kişinin fikrini açıklayabileceği hazır bir ortam varken, herhangi bir sebeple, bilinçli bir biçimde bunu yapmamayı seçmesi gerekmektedir (Hayes vd., 2005a)".

Medyadaki hâkim görüşün günlük yaşamımıza yansımasıyla birlikte bireyler kendilerini azınlık olarak hissetmeye başlarlar ve bu noktada suskunluk sarmalı işlemeye başlar. $\mathrm{Bu}$, bireyin gündelik yaşam pratiklerinde kendisini otosansür olarak göstermektedir. Bireylerin kendini ötekileştirilmiş hissetme duygusu, sansürle birlikte ortaya çıkan bir yalnızlaşma hissidir aslında. İktidarın 'marjinallik' hissini yaygınlaştırmasıyla kişinin kendini suskunluk sarmalı içinde bulması, otosansürün gelişmesi bakımından iktidara katkı sağlayan bir durum yaratmaktadır. Konuşmamayı seçmek yerine, otosansürü kıracak bir davranış yolu olarak konuşmayı tercih eden kişilerin yüzleştiği birtakım olumsuz durum ise, bu durumdan haberdar olacak birçok farklı kişiyi yeniden otosansür çemberinin içine çekmektedir.

İnsanların medyada olan biteni takip ettiklerinde tanık oldukları şeyler, kendi davranışlarını kontrol etme gereksinimi yaratmaktadır. Aslında amaçlanan, bir bakıma da bu düzeyde bir korku yaratarak kontrolü sağlamaktır. 2012 yılında yayınlanan AB İlerleme Raporu'nda da bu duruma dikkat çekilmiş ve medyaya yapılan baskılar birebir olarak otosansürün sebebi olarak gösterilmiştir.

Otosansürün yaygınlaşmasıyla birlikte ortada sansür edilmek istenecek bir verinin bile kalmaması riski vardır. $\mathrm{Bu}$ da aslında yaratılan korku durumunun, otoriteler tarafindan hedeflenen bir sonucudur. Günlük yaşamda bireyin kendini ifade 
etmeye daha fazla alıştığı sosyal medyadaki durum ise otosansürü çok farklı bir boyuta taşımaktadır. Bu yüzden gözetimin sosyal medyadaki varoluşunu incelemek önemlidir.

\section{2. Gözetim bağlamında sosyal medya}

İnternet herkes için, tüm dünyada olduğu gibi bir kendini ifade etme aracıdır. Aynı zamanda eşitliği de mümkün kılmaktadır. "Şu halde İnternet özgürlüğü, düşünce özgürlüğünü, telekomünikasyon yani medya özgürlüğünü ama aynı zamanda yaşayan bir demokrasi ve işlevsel bir Pazar için mutlaka zorunlu olan enformasyon özgürlüğünü içerir (Gören, 2014: 10)”. Elbette ki geleneksel medyaya göre çok daha özgür ve herkese açık oluşundan dolayı zararlı veya uygunsuz içerik üretimine açık bir yapı olduğu inkâr edilemez. Ancak sosyal medya sayesinde İnternet, geleneksel medyada konuşul(a)mayan konuların dile getirildiği ve her kesimin bir arada olduğu çok sesli bir yapı haline gelmiştir. Aynı zamanda kendini azınlıkta ya da ötekileştirilmiş hisseden grupların da seslerini duyurabildiği bir ortam olmuştur.

İnternet üzerindeki her türlü veri izlenmektedir. Yoğun sansür, yoğun gözetimi gerektirir. Zararlı içeriğin istenen biçimde engellenebilmesi için çok daha etkin bir gözetim sistemine ihtiyaç vardır. Bugün Türkiye nüfusunun \%52'sinin sosyal ağ kullanıcısı olması, nüfusun yarısının sadece İnternet üzerinden gözetim altına alınmış olduğunu göstermektedir.

Teknoloji kaynaklı ve siber güvenlik temelli gözetleme faaliyetlerinin aslında Foucault'nun disipliner amaçlı gözetim toplumu açıklamalarından pek de farkı yoktur. Kişi, iletişimin öznesi değil nesnesi konumuna düşecektir ve bu da gözetimin sonucu olarak suskunluk sarmalına da neden olmaktadır. "Muhtemelen Türkiye'de "mahalle baskısı" olarak nitelenen ilişkisel yapıyla gelen suskunluk sarmalı koşulunun olmadığını hiç kimse iddia edemez” (Erdoğan ve Alemdar, 2010: 179). Ayrıca dışlanma korkusuyla kendi kendini kısıtlama olarak ortaya çıkan bu davranış biçimini otosansüre benzetmek de yanlış olmayacaktır. Hayes vd. (2005b)'ne göre kimileri bu kuramı fazla basit buluyor olsa da, sosyal şartlar uygun olduktan sonra suskunluk sarmalının işleyeceğinden şüphe yoktur ve bu kuram otosansür ile ilgili 
yapılacak çalışmalara yol göstermeye devam edecektir.

\section{3. Facebook'ta kimlik temsili ve mahremiyet}

Facebook kurulduğu günden bugüne, günlük yaşamın içine dahil oldukça güçlenen bir yapıya kavuşmuştur. Genel olarak sosyal paylaşım ağları, kullanıcıların kendi kimliklerini yansıtan birer profil oluşturmasıyla kullanılmaya başlar. Facebook'ta da süreç bu şekilde işlemektedir. Facebook'ta kullanıcılar, kendi izleyicilerini ve bu izleyicilerle paylaşacakları veri miktarını kendileri seçerler. Facebook, kişisel bilgilerden fotoğraf paylaşımına kadar kullanıcıların kendi kimliklerini oluşturmasına olanak sağlamaktadır. Anonim ortamlarda bireylerin istedikleri gibi kimlik üretmeleri mümkündür. Ancak Facebook, kuralları itibarıyla da gerçek kimlik gerektiren bir sosyal ağ olduğundan, burada daha çok üzerinde durulması gereken, kişilerin kendi gerçek kimlikleri ve onların sunulma biçimleridir. Bir anlamda Facebook'la birlikte sosyal paylaşım ağlarındaki anonimliğin son bulduğunu söylemek mümkündür.

Facebook, insanların birbirlerini takip ederek neler yaptıklarını, ne düşündüklerini ve genel olarak nasıl olduklarını anlamaya çalıştıkları bir ortamdır ve temel işlevi kimlik üretimi üzerine kurulmuştur. Bu bağlamda Goffman'ın (2009) söylediklerine bakmakta yarar vardır. Goffman, bireylerin davranışlarındaki birçok faktörü kendilerinin dışarıdan algılanmayı istedikleri şekillerde geliştirdikleri bir sahne performansı olarak değerlendirmektedir. Bu her zaman bilinçli bir şekilde gelişmek zorunda da değildir. Sosyal şartların bireyi etkileyiş şekilleri de sahne performansı olarak yorumlanabilmektedir.

Mahremiyeti tanımlamak ve mahremiyetin gerekliliğini tartışmak gerçekten zordur. Mahremiyetle ilgili sorular sosyal temsiller ve etkileşimlerden doğmaktadır ve kamusal ve özel sosyal etkileşimler olarak ikiye ayrılarak incelenmelidir (Tüfekçi, 2008). Bu noktada Altman'ın mahremiyetle ilgili söyledikleri önem taşımaktadır. Altman mahremiyeti, bir tür bireylerarası sınır kontrolü süreci olarak görmektedir. Altman'ın mahremiyetiyle genel mahremiyet algısı arasındaki en önemli fark, Altman'ın hayatta başkalarının benliğine ulaşabilmesi için ideal bir seviye olduğunu savunmasıdır (Tüfekçi, 2008: 21). Bu noktada mahremiyetin gözetimle yakın 
ilişkiler içerisinde olduğu söylenebilmektedir. "Bir durum, konu ya da birey hakkında sahip olunan bilgi, yine bu durum, konu ya da birey üzerinde söz hakkını da ardı sıra getirir (Toprak, 2009: 143)". Bir kimsenin gizli tutmak istediği bir bilgi kişinin isteği dışında elde edildiğinde, bu durumu hem mahremiyet ihlali, hem de gözetim olarak değerlendirmek mümkündür.

Ancak Facebook'taki mahremiyetle ilgili farklı sayılabilecek bir durum ise, kullanıcıların da başkalarını gözetlemeleri ve başkaları tarafından gözetlenmek istemeleri durumudur. "Bireyler artık birilerini gözetlemek için onları gizlice takip etmek gibi eski yöntemlere başvurmak durumunda da değillerdir. Çünkü gizlenmek, artık ne eskisi kadar kolaydır ne de istenesidir (Toprak, 2009: 162)”. Daha önce bahsettiğimiz Goffman'ın benliğin sunumu kavramı da aslında bu ifşa isteğiyle örtüşmektedir.

$\mathrm{Bu}$ durumda Facebook’ta mahremiyet ve ifşa isteği arasında bir çelişkiye rastlıyoruz. Buradaki sorun aslında Facebook kullanımın temelde kullanıcıların hedef kitlelerine göstermek istedikleri bilgiyi ifşa etmesi üzerine kurulu olmasıdır. Ancak Facebook'la ilgili yapılan çalışmalarda en çok tartışılan konu, kullanıcıların gizlilik ayarlarını yeterince etkin kullanmamaları ve dahası önemsememeleriyle ilgilidir.

Tüm bunlardan anlaşılacağı üzere, kişisel verilere üçüncü kişilerin erişebilmesi tek sorun değildir. Facebook’un bu verileri nasıl koruduğu da geniş bir tartışma konusu olagelmiştir.

\section{Yöntem}

$\mathrm{Bu}$ çalışmanın amacı Facebook kullanıcılarının otosansür eğilimini ortaya çıkarmak ve bu otosansür davranışını ortaya çıkış sebepleriyle birlikte incelemektir. Çalışmanın amaçları doğrultusunda otosansür davranışları var olduğu şekilde betimlenmek istendiğinden bu çalışmaya tarama modeli uymaktadır. Çalışma aynı zamanda betimsel bir araştırmadır. $\mathrm{Bu}$ tür araştırmalarda "anket veya görüşme yoluyla sayısal veriler toplanır ve sorulara verilen cevapların dağılımını betimlemek amaciyla istatistiksel olarak analiz edilir (Creswell, 2005: 354)”. Bu yolla, "bir olgunun ya da evrenin karakteristik özelliklerinin betimlenmesi amaçlanmaktadır (Shield ve Rangarjan, 2013: 71)". 
Anketin katılımcılarını Facebook kullanıcıları oluşturmaktadır. $\mathrm{Bu}$ katılımcılar toplam 577 kişidir. Anket Facebook üzerinden paylaşılmış ve viral dağıtım yoluyla kullanıcılara ulaşılmıştır.

Görüşmeye geçilirken, görüşme yapılacak katılımcıların anket katılımcılarıyla benzerlik taşımasına özen gösterilmiştir. $\mathrm{Bu}$ bağlamda anket katılımcılarının yaş ve meslek bilgileri dikkate alınarak yeni bir örneklem oluşturulmuştur. $\mathrm{Bu}$ örneklem, görüşme yapmayı kabul eden iki öğrenci, iki akademisyen, iki doktor, bir oyuncu, bir asker, bir gazeteci, bir öğretmen ve bir kuaför olmak üzere toplam 11 kişiden oluşmaktadır. 11 katılımcının 8'iyle yüz yüze görüşülmüş, 3'üyle ise şehir dışında olmaları sebebiyle telefon ve Skype görüşmesi gerçekleştirilmiştir.

577 katılımcının 320'si kadın, 257'si ise erkek kullanıcılardan oluşmaktadır. Anketi dolduran katılımcıların en küçüğü 17, en büyüğü ise 62 yaşındadır. Katılımcıların en yoğun yaş aralığının \%41 ile 17-25 yaş arasında olduğu görülmektedir. Katılımcıların \%37'si 26-34 yaş, \%14'ü 35-43 yaş, \%6'sı 44-52 yaş ve \%3’ü 53-62 yaş aralığında yer almaktadır. Daha ileri yaş düzeyindeki her grupta katılımcı sayısının azaldığı görülmektedir. Buna göre en büyük grup en genç grupken, en küçük grup en yaşlı gruptur.

Katılımcıların eğitim durumları incelendiğinde en büyük oranı \%48 ile önlisans/lisans mezunlarının oluşturduğu görülmektedir. Lise mezunları \%25, yüksek lisans mezunları \%19, doktora mezunları ise \%7'dir. İlkokul ve ortaokul mezunlarının toplamı katılımcıların sadece \%0.9'unu oluşturmaktadır.

Katılımcıların \%28'i öğrenci, \%14'ü akademisyen, \%12'si beyaz yakalı, \%7'si öğretmen, \%7'si mühendis, \%7'si sanatçı/tasarımcı, \%6'sı medya çalışanı, \%4'ü esnaf/serbest meslek, \%3'ü kamu çalışanı, \%3'ü sağlık çalışanı, \%2'si ev hanımı, \%2'si işsiz, \%2'si emekli, \%1'i hukukçu ve \%1'i ise “diğer" olarak kaydedilmiştir.

$\mathrm{Bu}$ çalışmada veri toplama aracı olarak, alanyazın taraması, çevrimiçi anket ve yarı yapılandırılmış görüşme teknikleri kullanılmıştır. 
Facebook kullanım alışkanlıklarıyla ilgili hazırlanan çevrimiçi anket, kullanıcıların demografik özelliklerini yansıtan sorular, kullanıcıların Facebook kullanımlarıyla ilgili sorular ve iki ölçekten oluşmaktadır. Bu ölçeklerden ilki Facebook üzerinde otosansür eğilimini ölçmek amacıyla otosansüre eğilim ölçeğinden (Hayes vd., 2005a) Türkçeye çevrilmiş ve Facebook için uyarlanmıştır. “Oto-sansüre eğilim ölçeği, önceki sessizlik sarmalı modellerine ek olarak geliştirilmiş ve kutuplaşmış politik ortamın yarattığı tartışmalı konularla ilgili fikirlerin bastırılmasını incelemektedir (Filak vd., 2009: 368)”.

Facebook güven ölçeği ise daha önce yapılan bir çalışmada (Kalaman, 2011) kullanıcıların Facebook'a ne oranda güvendiklerini anlamaya yönelik olarak sorulan sorulardan sadeleştirilmiş ve uyarlanmıştır.

Geçerlik çalışması için, doktora derecesine sahip ve alanda uzman olan üç kişiden görüş alınarak bazı ifadeler güncellenmiş ve çevirideki gerekli düzeltmeler yapılmıştır. Ankete son hali verildikten sonra pilot uygulama yapılmıştır. Pilot uygulamaya, Anadolu Üniversitesi İletişim Bilimleri Fakültesi İletişim Tasarımı ve Yönetimi Bölümü’nün Facebook kullanıcısı olan 55 öğrencisi katılmıştır.

Hazırlanan sorular Google Documents üzerinden çevrimiçi ankete dönüştürülmüştür. Anketin yalnızca Facebook hesabı olan İnternet kullanıcılarını hedeflemesi nedeniyle Facebook üzerinden Google linki paylaşılarak viral dağıtımı gerçekleştirilmiştir. Bu dağıtım yoluyla anket, 22.11.2014 - 06.12.2014 tarihleri arasında 577 Facebook kullanıcısı tarafından cevaplanmıştır.

Görüşme sorularının geçerliği için yine alan uzmanı üç kişinin görüşü alınmış ve bu sorular bir pilot görüşme yapılarak denenmiştir. Pilot görüşmeden sonra herhangi bir değişiklik ihtiyacı duyulmadığından bu görüşme örnekleme eklenmiştir. Bununla birlikte görüşmeci ve katılımcılar arasında araştırma kapsamında verilen sözlerin tutulacağına dair karşılıklı sözleşme imzalanmıştır.

Görüşmeler 09.12.2014 - 16.12.2014 tarihleri arasında katılımcılardan randevu almak suretiyle gerçekleştirilmiştir. Görüşmelerin tarih, saat ve yer bilgilerini içeren görüşme takvimi Tablo 1.'de görülmektedir. 
Tablo 1. Görüşme Takvimi

\begin{tabular}{lllll}
\hline Görüşme No & Tarih & Saat & Yer & Süre \\
\hline Görüşme No 1 & 9 Aralık 2014 & 11.00 & Katılımcının ofisi & $15,47 \mathrm{dk}$. \\
Görüşme No 2 & 10 Aralık 2014 & 11.00 & Toplantı salonu & $21,47 \mathrm{dk}$. \\
Görüşme No 3 & 10 Aralık 2014 & 15.15 & Görüşmecinin ofisi & $25,23 \mathrm{dk}$. \\
Görüşme No 4 & 11 Aralık 2014 & 16.00 & Dr. muayenehanesi & $11,45 \mathrm{dk}$. \\
Görüşme No 5 & 12 Aralık 2014 & 13.00 & Katılımcının ofisi & $14,11 \mathrm{dk}$. \\
Görüşme No 6 & 14 Aralık 2014 & 15.45 & Skype görüşmesi & $30,52 \mathrm{dk}$. \\
Görüşme No 7 & 14 Aralık 2014 & 17.00 & Tiyatro kulisi & $14,14 \mathrm{dk}$. \\
Görüşme No 8 & 15 Aralık 2014 & 15.15 & Görüşmecinin ofisi & $27,54 \mathrm{dk}$. \\
Görüşme No 9 & 15 Aralık 2014 & 22.35 & Telefon görüşmesi & $28,03 \mathrm{dk}$. \\
Görüşme No 10 & 15 Aralık 2014 & 23.30 & Telefon görüşmesi & $32,15 \mathrm{dk}$. \\
Görüşme No 11 & 16 Aralık 2014 & 12.00 & Kuaför Salonu & $8,44 \mathrm{dk}$. \\
\hline
\end{tabular}

Görüşmeler esnasında katılımcıların izniyle ses kaydı yapılmıştır. 11 görüşme sonucunda toplamda 3 saat, 51 dakika, 5 saniyelik ses kaydı elde edilmiştir. Her bir görüşme sonrasında ses kayıtları yazıya dökülerek belgelenmiştir.

Araştırma verilerinin analizi sürecinde betimsel analiz yönteminden yararlanılmıştır. Betimsel analiz yaklaşımına göre, "elde edilen veriler, daha önceden belirlenen temalara göre özetlenir ve yorumlanır (Yıldırım ve Şimşek, 2013: 256)”.

Yarı yapılandırılmış görüşme verileri de ankette olduğu gibi betimsel analiz yöntemiyle çözümlenmiştir. $\mathrm{Bu}$ doğrultuda betimsel analiz yönteminin dört aşamasına uyularak betimsel analiz için bir çerçeve oluşturulmuş, tematik çerçeveye göre veriler işlenmiş, bulgular tanımlanmış ve son olarak da bulgular yorumlanmıştır (Yıldırım ve Şimşek, 2013: 256).

\section{Bulgular ve yorum}

\subsection{Katılımcıların Facebook kullanım alışkanlıkları}

Katılımcıların ne kadar zamandır Facebook kullandığıyla ilgili verilere bakıldığında; katılımcıların \%29'u 7 yıldır, \%22'si 6 yıldır, \%14'ü 5 yıldır, \%11'i 8 yıldır, \%8'i 4 yıldır, \%5'i 10 yıldır,\%4'ü 3 yıldır, \%3'ü 2 yıldır, \%2'si 9 yıldır, \%1'i ise 1 yıl veya daha az süredir Facebook kullanmaktadır. $\mathrm{Bu}$ verilere göre katılımcıların \% 70'ten fazlası en az 5 yıllık Facebook kullanıcısıdır. 
Görüşme yapılan katılımcılardan ise 6's1 en az 5 yıldır, 5'i en az 2 yıldır Facebook kullanmaktadır. Katılımcıların Facebook kullanım amaçlarıyla ilgili veriler şöyledir: Katılımcılardan Facebook kullanım amaçlarını belirten üç seçenek işaretlemeleri istenmiş, ayrıca açık uçlu olarak cevaplayabilecekleri "Diğer” seçeneği de eklenmiştir.

“Tanıdıklarımla iletişim kurabilmek için”, “Gündemi takip edebilmek için” ve "Çevremdeki gelişmelerden haberdar olmak için" katılımcıların en çok işaretledikleri üç seçenek olduğundan en yoğun kullanım amaçları olarak gösterilebilmektedir. Buna göre, 495 kişi “tanıdıklarımla iletişim kurabilmek için”, 380 kişi “çevremdeki gelişmelerden haberdar olmak için”, 207 kişi "gündemi takip edebilmek için”, 166 kişi “kendimi ifade edecek paylaşımlarda bulunmak için”, 140 kişi “boş zamanımı değerlendirebilmek için”, 80 kişi “eğlence için”, 38 kişi “yeni insanlarla tanışmak için” yanıtını vermiştir. "Diğer" seçeneğini işaretleyenlerden 5 kişi mesleki amaçlar için, 4 kişi tanıtım amaçları için, 6 kişi dersler için, 2 kişi alışkanlık olduğu için, 1 kişi "stalking” amaçları için, 1 kişi de özellikle fotoğraf paylaşmak için Facebook kullandığını belirtmiştir.

Görüşme yapılan katılımcılardan 6 kişi tanıdıklarıyla iletişim kurmak için, 4 kişi ders gruplarını takip etmek için, 3 kişi mesleki amaçlarla, 2 kişi eğlence için, 1 kişi de gündemi takip edebilmek için Facebook kullandığını belirtmiştir. Katılımcıların bazıları birden fazla cevap vermiştir.

Katılımcıların hangi siklıkla Facebook'u ziyaret ettikleri sorusuna katılımcıların \% 54'ü "günde birkaç kez" yanıtını vermiştir. Bunu \% 39 ile "gün içinde sıklıkla" yanıtı izlemektedir. Katılımcıların \%7'si "haftada birkaç kez" yanıtını vermiştir. "Ayda birkaç kez” ve “yılda birkaç kez veya daha az” seçeneğini işaretleyenlerin toplamı ise yalnızca \%0.9'dur. Bu sonuca göre ankete katılım sağlayan Facebook kullanıcılarının büyük bir çoğunluğunun her gün Facebook kullandığını söylemek mümkündür.

Görüşme yapılan katılımcılardan 6 kişi gün içinde sıklıkla, 5 kişi ise günde birkaç kez Facebook'u ziyaret ettiğini belirtmiştir. Buna göre görüşme yapılan katılımcıların tamamı her gün mutlaka Facebook'u ziyaret etmektedir. Yine de 
katılımcıların kullanım biçimlerinde birtakım farklılıklar gözlenmiştir. Örneğin Katılımcı 6 kullanım yoğunluğunu, "Uyumadığım zamanların tamamında Facebook'ta sayılabilirim. Android telefon kullanıyoruz sonuçta. Her dakika zaten açık. Artık alışkanlık da yaptı herhalde...” şeklinde ifade etmiştir. Katılımcı 11 ise, "Bazen 1 saat, bazen 15 dakika, bazen de yarım gün oturduğum oluyor." diyerek her gün mutlaka Facebook’a girdiğini fakat sürenin farklılık gösterdiğini belirtmiştir.

Katılımcıların Facebook'ta ortalama ne kadar zaman geçirdikleriyle ilgili verilere bakıldığında; birbirine yakın dağılımlar oluştuğunu görmekteyiz. Buna göre kat1lımc1ların \%29'u 15-30 dakika, \%28'i 30-60 dakika, \%26's1 1-3 saat, \%11'i 3 saatten fazla ve \%7'si birkaç dakika Facebook'ta zaman harcadığını belirtmiştir.

Katılımcıların Facebook’a hangi araçlarla erişim sağladıkları sorulmuştur. Soruda katılımcılara "bilgisayar", "akıllı telefon" ve "tablet" seçenekleri arasından birden fazla işaretleme yapabilecekleri belirtilmiştir. Buna göre katılımcıların \%52'si bilgisayar ve akıllı telefon kullandığını belirtmiştir. \%17'si her üç aracı, \%15'i sadece bilgisayar, \%10'u sadece ak1llı telefon, \%4'ü tablet ve ak1llı telefon, \%3'ü bilgisayar ve tablet, \%0.5'i ise sadece tablet kullandığını belirtmiştir.

Bu durumda kullanıcıların \%85.8'i erişim araçlarından biri olarak bilgisayar, \%82'si akıllı telefon kullanmaktadır. Buna rağmen katılımcıların sadece \%23.8'i erişim araçlarından biri olarak tablet kullanmaktadır.

Türkiye'deki kullanıcıların \%68'i paylaşımlarında bilgisayar, \%28'i cep telefonu ve \%4'ü tablet kullanmaktadır (Kemp, 2015: 319). Buna göre yukarıdaki verilerin Türkiye geneliyle örtüştüğünü söylemek yanlış olmayacaktır.

Görüşme yapılan katılımcıların ifadelerine göre Facebook'a bilgisayar üzerinden erişim sağlayan 9 kişi, akıllı telefon üzerinden erişim sağlayan 9 kişi, tablet üzerinden erişim sağlayan 3 kişi vardır.

Akıllı telefon kullanan katılımcılar, Facebook üzerinde çok daha fazla zaman harcadıklarını belirtmişlerdir. Örneğin Katılımcı 10 kullanım yoğunluğunu, "Bilgisayardan kullanırken biraz daha seyrek aralıklarla Facebook'ta zaman harcadığımın farkındayım. Ama ne yazık ki bu akıllı telefonlarla beraber, biraz da gelen uyarılarla, orada gördüğünüz bildirimlerle, herkes öyle mi bilmiyorum ama 
bende durum ne yazık ki sıklaştı" şeklinde belirtmektedir. Katılımeı 1 ise bu durumdan duyduğu rahatsızlığı, "Yakın döneme kadar cep telefonumda da aplikasyonu vard1. Fakat oradan da farklı saatlerde mesajlar gelmeye başlayınca beni çok meşgul ettiğini düşünerek aplikasyonu kaldırdım” diyerek sadece bilgisayar üzerinden erişim sağlamayı tercih ettiğini belirtmiştir.

Türkiye'de ak1llı telefonlar üzerinden İnternet erişimi oranı \%28'dir ve bu oran y1lda \%62 oranında artış göstermektedir (Kemp, 2015: 319). Bu da her yıl akıllı telefon kullanıcısının artmasıyla birlikte Facebook'ta geçirilen toplam zamanın da artması olarak yorumlanabilir.

Katılımcıların profillerini güncelleme sıklığıyla ilgili verilere göre; katılımcıların \%30'u “birkaç ayda bir”, \%25'i “ayda birkaç kez”, \%22'si “yılda birkaç kez veya daha az”, \%17'si "haftada birkaç kez”, \%3'ü "günde birkaç kez” ve $\% 2$ 'si "gün içinde sıklıkla" cevabını vermiştir.

Verilere göre kullanıcıların büyük bir çoğunluğunun her gün Facebook'u ziyaret ettiği görülmüştür. Buna rağmen kullanıcıların yalnızca \%53’ü her gün paylaşım yaptığını söylemektedir. Bu durumda kullanıcıların paylaşım yapmasalar da Facebook’ta zaman geçiriyor oldukları söylenebilmektedir.

Görüşme yapılan katılımcıların 3'ü günde birkaç kez, 2'si birkaç ayda bir, 2'si haftada birkaç kez, 2'si ayda birkaç kez, 1'i yılda birkaç kez veya daha az profil güncellediğini, 1’i ise düzenli bir aralığın olmadığını belirtmiştir.

Katılımcıların Facebook’taki arkadaş sayılarıyla ilgili verilere bakıldığında; “Facebook’ta kaç arkadaşınız var?” sorusunu katılımcıların \%58'i “101-500 arası”, \%24'ü “501-1000 arası” olarak cevaplamıştır. \%8'i “1000'den fazla”, \%6's1 50-100 arası”, \%2'si ise “0-50 arası” cevabını vermiştir.

Görüşme yapılan katılımcılardan 5'i 500-1000 arası, 3'ü 100-500 arası, 3'ü ise 1000 'den fazla arkadaşı olduğunu belirtmiştir.

\subsection{Katılımcıların gizlilik konusundaki tutumu}

Katılımcıların Facebook’ta kimleri arkadaş olarak kabul ettiğiyle ilgili veriler şöyledir: Katılımcıların \%69'u “kendi tanıdıklarım”, \%24'ü “kendi tanıdıklarım ve 
onların arkadaşları" cevabını vermiştir. Katılımcıların yalnızca \%6'sı “arkadaş olmak isteyen herkesi” cevabını vermiştir. $\mathrm{Bu}$ durumda katılımcıların çoğunluğunun tanımadıkları kişileri Facebook’ta kabul etmedikleri görülmektedir.

Görüşme yapılan katılımcılar arasından 10 kişi tanımadı̆̆ Facebook'ta arkadaş olarak kabul etmediğini ifade etmiştir. Yalnızca Katılımcı 9, Facebook’u profesyonel olarak da kullandığg için tanımadığı kişileri iş amaçlı kabul ettiğini belirtmiştir.

Katılımcılar genellikle ortak arkadaş sayısının arkadaşlık için önemli bir referans olduğunu belirtmektedirler. Buna örnek olarak Katılımcı 1, “Ortak bir arkadaşımız olan birisi bana arkadaşlık isteği gönderebiliyor. Onda da bakıyorum kimmiş, gerçekten benim hayatımda iyi tanıdığım birisinin arkadaşı mı ve hatta sayfasının izin verdiği ölçüde bir ortak paydamız da var mı arkadaş dışında..." diye görüş belirtmiştir. Buna rağmen Katılımcı 8, "Ortak arkadaş vesaire de fark etmiyor. Herhangi bir diyaloğum olmayan hiç kimseyi arkadaş olarak kabul etmiyorum" demiştir.

Katılımcıların Facebook’taki kişisel bilgilerini kimlerin görebildiğiyle ilgili verilere bakıldığında; katılımcıların \%70’i “sadece arkadaşlarım” yanıtını vermiş, \%14'ü özel ayarlar kullandığını belirtmiştir. \%6'sı “herkes”, \%7'si “sadece ben”, \%4’ü arkadaşlarımın arkadaşları olarak yanıtlamıştır.

Görüşme yapılan katılımcılardan 8'i kişisel bilgilerinin sadece arkadaşları tarafından görüntülenebildiğini belirtmiştir. Yalnızca 1'`i sadece kendisinin görebildiğini belirtirken, Katılımcı 9 ise profesyonel kullanımından dolayı gizliliğe önem vermediğini söylemiştir. Katılımcı 9 bu görüşünü şöyle aktarmaktadır: “Gizlilik ayarlarını biliyorum ama kullanmıyorum. Çünkü benim kimseden gizlim saklım olmadığı için, tam tersine ne kadar çok kişiye erişirsem... Yani bir haberci olduğum için, yaptığım haberler, yazdığım makaleler herkese açık olduğu için benim gizlilik ayarlarım açıktır. Ama gizlilik ayarlarını kullanmayı biliyorum. Ama ben kişisel ya da ailemle ilgili şeyleri paylaşacak olsaydım gizlilik ayarlarını kullanırdım.” Bu konuda Katılımcı 2, "Bir kere dışarıdan, yani arkadaşımın arkadaşı 
da olsa benim onayım olmadan profilimi göremiyor. Bu şekilde yapılandırdım. Özellikle fotoğraflara dikkat ediyorum" demiştir.

Buna göre katılımcılar, kişisel bilgilerinin korunmasına önem vermektedir ve tanımadıkları kişilerle paylaşmak istememektedir.

Katılımcıların Facebook gizlilik ayarlarını yeterince etkin kullanıp kullanamadığına ilişkin verilere göre; katılımcıların \%71'i gizlilik ayarlarını etkin kullanabildiğini düşünmektedir. \%25'i kullanamadığı belirtirken, yalnızca \%4'ü bu konu hakkında bilgisi olmadığını söylemiştir.

$\mathrm{Bu}$ konuyla ilgili katılımcılar yüksek oranda gizlilik ayarlarını etkin kullanmakta olduklarını düşünmektedirler. Buna rağmen, kullanıcılardan varlığını bilmedikleri birtakım özelliklerle ilgili görüş bildirmelerini beklemek de doğru olmayacaktır. Bununla ilgili Katılımcı 10’un söyledikleri önemlidir. Katılımcı 10, "Gizlilik ayarlanı başlarda daha az bilgili olduğum dönemdi. Aile fertlerimin yardımıyla zaten ilerlemişti kullanım dönemim. O dönemde bir şeyler yapıldı... Sadece arkadaşlarımın görebildiği kadarıyla...” demiş işin teknik yönünü çok da iyi bilmediğini ifade etmiştir. Bir yandan da gizlilik ayarlarına önem veren Katılımcı 3, “Aslında ben inanıyorum ki Facebook'ta bazen, 'gizlilik ayarlarınızın görünmemesi için şu kutucuğu işaretleyin' gibi şeyler dolaşıyor. Onu etkin bir şekilde kullanamadım. Hatta bize çok fazla bilgi verilmediğini düşünüyorum” demektedir. Kullanıcıların gizlilik ayarlarını en etkin şekilde kullanabilmeleri için bu özelliklerin iyi tanıtılması gerekir. Facebook'un bu konudaki tutumuyla ilgili tartışmalara alan yazın bölümünde yer verilmiştir.

Facebook'ta her bir paylaşıma özel olarak gizlilik ayarlarını yapılandırmaya yarayan "hedef kitle tercih aracı" bulunmaktadır. Katılımcıların Facebook paylaşımlarını herkesin görmemesi için hedef kitle tercih aracını kullanıp kullanmadığı ile ilgili verilere bakıldığında; katılımcıların \%68'i bu aracı kullandığını, \%21'i kullanmadığını, \%11'i ise bu konu hakkında bilgisi olmadığını belirtmiştir.

Katılımcıların paylaşımlarını en çok kimlerin görmesiyle ilgili tereddüt yaşadıklarıyla ilgili verilere bakılırsa; katılımcıların \%57'si “kimseyle ilgili tereddüt 
yaşamam” yanıtını vermiştir. \%13'̈̈ “akrabalarım”, \%9'u "hocalarım/patronlarım”, \%5'i “ailem”, \%5'i “öğrencilerim/çalışanlarım”, \%3'ü “iş/okul arkadaşlarım”, \%3’ü “arkadaş çevrem” yanıtını vermiştir. "Diğer" seçeneğini işaretleyen katılımcılar düşük oranlarda; devlet, eski sevgililerim, gerici yobazlar, hastalarım, hem öğrencilerim, hem arkadaş hem de iş çevrem, hoşlandığım kişi, hoşlanmadığım kişiler, istismarcılar, karşı siyasi görüşlü arkadaşlar, kötü amaçlı kişiler, zamanında tanıştığım fakat artık pek görüşmediğim kişiler olarak belirtmişlerdir.

Görüşme yapılan katılımcılardan 2 kişi akrabalarıyla ilgili, 2 kişi öğrencileriyle ilgili, 1 kişi hocalarıyla ilgili, 1 kişi meslektaşlarıyla ilgili, 1 kişi ailesiyle ilgili tereddüt yaşadığını 1 kişi de yine profesyonel kullanımdan ötürü kimseyle ilgili tereddüt yaşamadığını belirtmiştir. 2 kişi ise özellikle bir kesimden bahsetmemiştir. Bunlardan Katılımcı 6, herkesle ilgili dikkatli olunması gerektiğini, "Sonuçta bir toplumsal yaşamın içerisinde yaşıyoruz. Benim belki inandığım bir şey insanları rahatsız edebilir. Açıkçası Don Kişot olmanın da manası yok" sözleriyle açıklamaktadır. Katılımcı 2 ise akrabalarıyla ilgili yaşadığı sıkıntının boyutunu şu sözleriyle açıklamaktadır: "Bunu baştan belirtmem gerekirdi belki. Benim iki Facebook hesabım var. Birinde tamamen okul için açtığım, diğerinde de akrabalar memleketimdeki arkadaş çevrem vs... O ‘senin niye Facebook hesabın yok' diyenler için açtığım hesaptır. Orada aktifliğim neredeyse hiç yok.”

Anketin sonuçlarına göre hiç kimseden çekinmediğini belirtenlerin oranı en yüksek görünmektedir. Kullanıcıların başka kullanıcılarla ilgili tereddüt yaşamaması onların Facebook'ta otosansür uygulamadığını gösteren bir faktör değildir. Yukarıda Katılımcı 6'nın herkesle ilgili yaptığı yorum buna örnek olarak gösterilebilir. Ayrıca belirli kişilerle ilgili tereddüt yaşanmıyor olması, kullanıcıların paylaşımlarındaki genel tavir olarak sayılamayacaktır.

\subsection{Katılımcıların otosansüre ilişkin görüşleri}

Katılımcıların mesleklerinin veya konumlarının paylaşımlarını etkileyip etkilemediğine dair verilere göre; katılımcıların \%37'si “hayır”, \%30'u “kısmen”, \%28'i "evet" demiştir. 
Görüşme yapılan kullanıcılardan bu soruya yanıt verenlerin ise tamamı mesleklerinin paylaşımlarında etkili olduğunu belirtmiştir. Bununla ilgili Katılımcı 1, mesleğinin çok fazla etkili olduğunu söylerken Katılımcı 6, "Ben devlet görevinde çalışıyorum. Senin okulundaki hocalar bile doğru dürüst paylaşım yapamıyor ki... Benim mesleğim çok daha bu anlamda katı kurallara sahip. Tabi ki de kısıtlıyorum kendimi” demektedir. Katılımcı 6, özellikle mesleğiyle ilgili paylaşım yapmaktan kaçındığııı, bazı davranışların yargılanma sebebi bile olabileceğini düşündügüunü aktarmaktadir.

Katılımcıların Facebook üzerinden otosansüre ilişkin görüşlere katılım durumları Tablo 2.'de yer almaktadır.

Tablo 2. Otosansüre eğilim ölçeğine verilen yanıtlar

\begin{tabular}{|c|c|c|c|c|c|}
\hline & 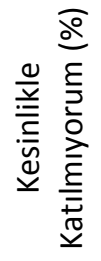 & 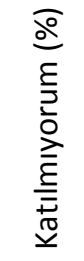 & 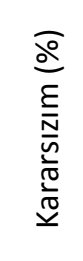 & 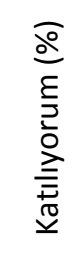 & 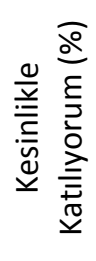 \\
\hline $\begin{array}{l}\text { Facebook'ta başkalarının farklı düşündüğünü bildiğimde } \\
\text { fikrimi belirtmek benim için zordur. }\end{array}$ & 32.1 & 48.4 & 10.2 & 8.3 & 1.0 \\
\hline $\begin{array}{l}\text { Facebook'ta arkadaşlarımın hatalı olduğunu düşünsem de } \\
\text { çoğu zaman bunu dile getiremem. }\end{array}$ & 19.6 & 38.3 & 17.5 & 22.4 & 2.3 \\
\hline $\begin{array}{l}\text { Facebook'ta başkalarına katılmadığım zaman tartışmaya } \\
\text { girmek yerine sessiz kalmayı tercih ederim. }\end{array}$ & 13.2 & 31.2 & 20.8 & 26.0 & 8.8 \\
\hline $\begin{array}{l}\text { Facebook'ta benden farklı düşünen insanlarla fikrimi } \\
\text { paylaşmak benim için kolaydır. }\end{array}$ & 4.2 & 16.3 & 17.7 & 43.7 & 18.2 \\
\hline $\begin{array}{l}\text { Facebook'ta tartışmalı konular hakkında açıkça paylaşım } \\
\text { yapmak yerine sessiz kalmak daha kolaydır. }\end{array}$ & 14.4 & 28.6 & 18.0 & 27.2 & 11.8 \\
\hline $\begin{array}{l}\text { Facebook'ta başkalarına katılmadığım zaman bunu onlara } \\
\text { söylemekte sorun yaşamam. }\end{array}$ & 4.2 & 12.7 & 16.3 & 44.2 & 22.7 \\
\hline
\end{tabular}

“Facebook'ta başkalarının farklı düşündüğünü bildiğimde fikrimi belirtmek benim için zordur" ifadesine katılımcıların verdiği katılmıyorum ve kesinlikle katılmıyorum ifadeleri toplandığında \%81 olumsuz yanıt vermişlerdir.

“Facebook'ta arkadaşlarımın hatalı olduğunu düşünsem de çoğu zaman bunu dile getiremem" ifadesine toplam $\% 60$ oranında katılmıyorum ve kesinlikle katılmıyorum yanıtı vermişlerdir. 
"Facebook'ta başkalarına katılmadığım zaman tartışmaya girmek yerine sessiz kalmayı tercih ederim.” ifadesine \%44 oranında olumsuz görüş bildirilmiştir.

"Facebook'ta benden farklı düşünen insanlarla fikrimi paylaşmak benim için kolaydır." ifadesine \%21 oranında olumsuz görüş bildirilmiştir.

“Facebook'ta tartışmalı konular hakkında açıkça paylaşım yapmak yerine sessiz kalmak daha kolaydır." ifadesine \%43 oranında olumsuz katılım olmuştur.

"Facebook'ta başkalarına katılmadığım zaman bunu onlara söylemekte sorun yaşamam.” ifadesine \%17 oranında katılmıyorum ve kesinlikle katılmıyorum yanıtı alınmıştır. İfadelere verilen yanıtların her maddeye göre oranı tabloda ayrıntılı yer almaktadır.

Ankete verilen yanıtlara genel olarak bakıldığında, her maddeye verilen yanıtlar çeşitlilik gösterse de katılımcıların çoğunluğunun kendilerini ifade etmekte zorlanmadıkları gibi bir sonuç görünmektedir. Aşağıda konuya ilişkin görüşme sorularına verilen yanıtlar yer almaktadır.

Görüşme yapılan katılımcıların söylediklerine göre katılımcıların Facebook'ta yeterince rahat paylaşım yapamamalarıyla ilgili farklı sebepler bulunmaktadır. Katılımcı 2 Facebook'u kamusal alan olarak gördügü için paylaşılanlara dikkat edilmesi gerektiğini belirtmiştir: "Şöyle tarif edeyim. Bir grup insanla evdeyken daha rahatsınızdır. Okula geldiğinizde sosyal hayata kavuştuğunuzda biraz daha derli toplu olursunuz. Facebook da benim için bunu ifade ediyor. Orası sadece benim değil. Pek çok insanla paylaştığımız yer. Çünkü orası kapalı alan değil. Kamusal alan gibi bir şey... Dikkatli olunması bana göre uç bir hareket değil."

Katılımcı 3 ise işi dolayısıyla kendini rahat hissedemediğini söylerken otosansürden bahsetmektedir: "Artık işim dolayısıyla kendimi engellemem, frenlemem gerekiyor. Çünkü patronumun bir şekilde devletle bağlantısı var ve o yüzden bir şey yazarken aslında devletle alakalı çok fazla şeye değinmemeye çalışıyorum. Aslında bir nevi otosansür oluyor. Günlük hayatta dile getirdiğim şeyler, size dile getirdiğim şeyler sizde kalıyor. Kayıtlı bir yerde durmuyor o yüzden. Facebook'ta kayıtlı olduğu için ve herkes o tarihte o gönderiye ulaşabileceği için kendimi tam ifade etmekten kaçınıyorum." 
Facebook'u gündelik yaşamdaki gibi kullanmayı hedeflemeyen kullanıcılarda ise çok fazla sorun yaşanmadığı söylenebilir. Bunu Katılımcı 5, "Facebook'u her konuda kendimi ifade edeceğim ya da her konunun dillendirileceği bir platform olarak görmüyorum. Sınırlarımı belirledim. O sınırlar içinde çok rahat paylaşımlarımı yapabiliyorum" diyerek açıklamaktadır.

$\mathrm{Bu}$ noktada paylaşımların içeriğinin önemli olduğunu belirtmek gerekmektedir. Görüşme yapılan katılımcıların 11'inden 10'unda ortak çıkan bir sonuç, siyasi içerikli paylaşım yapmaktan çekiniyor olmalarıdır. Kullanıcıların bazıları gözetim altında olduklarını düşündüklerinden dolayı siyasi paylaşımdan çekindiklerini belirtirken, bazıları ise bu konularda başkalarıyla tartışmaya girmek istemediklerinden bahsetmiştir.

Bu konuyla ilgili Katılımcı 7, “Güzel bir et yediysem bunun gibi günlük konular paylaşılabiliyorum. Siyasi içerikleri ne yazık ki paylaşamıyorum. Beni zora sokacak siyasi açılımsa genellikle kendim otokontrol koyuyorum" demiştir. Katılımcı 8 ise, "Mesela politik konularda Facebook'ta paylaşım yapmaktan hoşlanmıyorum. Politik anlamda çok farklı düşündüğüm insanlar da var. Kimine göre fazla liberal kalabiliyorum. Kimine göre daha solda, daha anarşist durabiliyorum" diyerek bu konuda Facebook arkadaşlarıyla tartışmaya girmek istemediğini belirtmiştir. Yalnızca Katılımcı 11 herhangi bir çekincesi olmadığını belirtmiş, "Bir şey paylaşacaksam, düşündüysem, korkacağım hiçbir şey yoktur. Yayınlarım. Arkadaşlarıma gönderirim. İnceleyen inceler, yorumunu yapmak isteyen yapar" demiştir.

Görüşme yapılan katılımcılarla çevrimiçi ankete katılan katılımcıların otosansür konusuna yaklaşımlarında bazı farklılıklar gözlenmiştir. Anket sonuçları birbirine yakın çıkmış olsa da katılımcılar arasında daha geniş bir grup genellikle Facebook'ta çekinecek herhangi bir durum olmadığına yönelik fikir beyan etmiştir. $\mathrm{Bu}$ durum Facebook’taki otosansürün fikir beyan etmekten çok kimlik sunumuyla ilişkili olmasıyla açıklanabilmektedir. Görüşme verileri de bu durumu desteklemektedir. 


\subsection{Katılımcıların Facebook'un güvenilirliğine ilişkin düşünceleri}

Anket katılımcılarının Facebook'un güvenirliğine ilişkin düşünceleri aşağıda Tablo 3.'te yer almaktadir.

Tablo 3. Facebook'un güvenirliğine ilişkin görüşler

\begin{tabular}{|c|c|c|c|c|c|}
\hline & 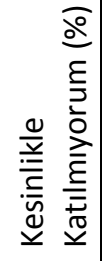 & 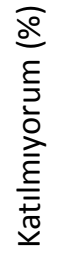 & 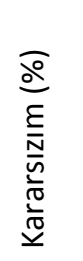 & 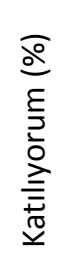 & 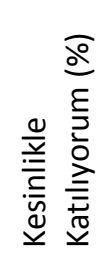 \\
\hline $\begin{array}{l}\text { Facebook'un günümüzün vazgeçilmez bir iletişim aracı } \\
\text { olduğunu düşünüyorum. }\end{array}$ & 8.5 & 14.7 & 13.0 & 40.6 & 23.2 \\
\hline Facebook'un güvenli bir alan olduğunu düşünüyorum. & 33.1 & 35.0 & 24.1 & 6.6 & 1.2 \\
\hline $\begin{array}{l}\text { Facebook'un olumsuz etkilerinin olumlu etkilerinden daha } \\
\text { fazla olduğunu düşünüyorum }\end{array}$ & 4.9 & 26.9 & 34.1 & 21.0 & 13.2 \\
\hline $\begin{array}{l}\text { Facebook'un kullanıcıların özel hayatına müdahaleyi } \\
\text { kolaylaştırdığını düşünüyorum. }\end{array}$ & 5.2 & 13.3 & 10.7 & 44.4 & 26.3 \\
\hline $\begin{array}{l}\text { Facebook'un kişisel bilgilerimi, fotoğraf ve videolarımı } \\
\text { güvenli bir biçimde koruduğunu düşünüyorum. }\end{array}$ & 30.7 & 28.2 & 30.0 & 9.2 & 1.9 \\
\hline $\begin{array}{l}\text { Facebook'un fotoğraf ve video yüklemek için sakıncalı bir } \\
\text { yer olduğunu düşünmüyorum. }\end{array}$ & 13.2 & 22.4 & 34.7 & 25.1 & 4.7 \\
\hline $\begin{array}{l}\text { Facebook'un fotoğraf ve videolarımın korunması için yeterli } \\
\text { önlemi aldığını düşünüyorum. }\end{array}$ & 23.9 & 28.8 & 32.1 & 13.5 & 1.7 \\
\hline $\begin{array}{l}\text { Facebook'un istemediğim ve/veya tanımadığım kişileri bilgi } \\
\text { fotoğraf ve videolarıma ulaştıracağından korkuyorum. }\end{array}$ & 7.1 & 19.6 & 24.4 & 35.4 & 13.5 \\
\hline
\end{tabular}

"Facebook'un günümüzün vazgeçilmez bir iletişim aracı olduğunu düşünüyorum.” ifadesine verilen yanıtların yığıldığı yanıtlara bakıldığında, katılımcıların toplam \%64 oranında olumlu görüş bildirmişlerdir.

"Facebook'un güvenli bir alan olduğunu düşünüyorum" ifadesiyle ilgili verilere bakıldığında katılımcılar \%68 oranında olumsuz görüş bildirmişlerdir. Ayrıca \%24 oranında kararsızım seçeneğine yönelmeleri dikkat çekmektedir.

"Facebook'un olumsuz etkilerinin olumlu etkilerinden daha fazla olduğunu düşünüyorum" ifadesiyle ilgili olarak yanıt dağılımına bakıldığında en çok \%34 ile kararsızım seçeneği görülmektedir. Olumsuz yanıtlar ise \%32’dir. 
"Facebook'un kullanıcıların özel hayatına müdahaleyi kolaylaştırdığını düşünüyorum" ifadesine katılım oranı; katılıyorum ve kesinlikle katılıyorum seçeneklerinin toplamına bakıldığında \%71' dir.

"Facebook'un kişisel bilgilerimi, fotoğraf ve videolarımı güvenli bir biçimde koruduğunu düşünüyorum" ifadesine olumsuz görüşler \%39 oranındadır. Ayrıca \%30 kararsızım yanıtı dikkat çekmektedir.

"Facebook'un fotoğraf ve video yüklemek için sakıncalı bir yer olduğunu düşünmüyorum" ifadesine \%36 oranında olumsuz görüş bildirilmiştir. Ayrıca \%35 kararsızım yanıtı en çok yanıtlanan seçenektir.

"Facebook'un fotoğraf ve videolarımın korunması için yeterli önlemi aldığını düşünüyorum” ifadesine katılımcılar \%53 oranında olumsuz yanıt vermişlerdir. Kararsızım diyenler \%32 oranılla dikkat çekmektedir.

"Facebook'un istemediğim ve/veya tanımadığım kişileri bilgi, fotoğraf ve videolarıma ulaştıracağından korkuyorum” ifadesine katılıyorum ve kesinlikle katılıyorum ifadelerine toplam olarak bakıldığında \%49 oranında olumlu katılım görülmüştür. Ayrıca \%24 oranında kararsızlar bulunmaktadır.

Ankete verilen yanıtlara bakıldığında, katılımcıların çoğunluğunun Facebook'ta paylaşılan kişisel verilerinin güvenliğinden pek emin olmadıkları, özel hayata da müdahale edebileceği bilgisine sahip oldukları kolaylıkla söylenebilir. Konuya ilişkin görüşme sorularına verilen yanıtlar aşağıda yer almaktadır.

Görüşme yapılan katılımcılar "Facebook'u güvenli buluyor musunuz?" sorusuna genellikle "Hayır" yanıtını vermişlerdir. Bu sonuçlara göre en çok bahsedilen sorun, Facebook'un verileri saklıyor olması ve üçüncü partilerle paylaşıyor olma ihtimalidir. Katılımcıların çoğu bu durumu bir gözetim olarak değerlendirmişlerdir.

Katılımcı 3 bu durumu, “Aslında kendi rızamızla özel hayatımızı sergiliyoruz. Çok da onayladığım bir şey değil. Bir nevi fişleme gibi geliyor bana. Güvenlikle ilgili. Nerede ne zaman bulunduğum ve ne yaptığım bir şekilde orada bulunuyor" şeklinde değerlendirmiştir. Katılımcı 4, "Hayır. Fotoğraflar açısından... Herkes rahatlıkla ulaşabiliyor, indirebiliyor, kaydedebiliyor" demiştir. Katılımcı 7 de 
güvenli bulmadığını, "Hayır. Tabi ki bulmuyorum. Bir veri tabanının hükümetle ya da hükümetlerle paylaşıllyor olması, dünya çapında da birçok ülkede böyle" diyerek açıklamaktadır.

Verilerin üçüncü partilerle paylaşılmasıyla ilgili Katılımcı 8, çok önemli bilgiler gerekmediğini, "Mutlaka yasadışı bir şey yapmanız gerekmiyor bir şeyleri gizlemeniz için, onun kişisel veri olması için..." sözleriyle ifade etmiştir. Katılımcı 9 ise herkesin gözetim altında oluşuyla sosyal medya arasında ilişki kurmuştur: "Sadece sosyal medya değil, İnternete düşen hiçbir şeyin güvencesi yok. Çünkü sosyal medya dünyadaki en büyük Big Brother. Gözetleme yeri diyebiliriz. Milyarlarca insanın bir şekilde gözetim altında, paylaşımları, yaptıkları, nasıl bir ruh hali içinde oldukları açısından... Zaman zaman çıkan haberler de gizli servislerin sosyal medya teknoloji firmalarından birtakım talepleri olduğu, gerçi karşılanmadığ falan da söyleniyor ama ben yine de hiç güvenli bulmuyorum." Anket sonuçlarıyla görüşme analizlerine göre kullanıcıların Facebook'la ilgili ciddi bir güven sorunu yaşadıkları açıkça görülebiliyor.

\section{Sonuç}

Sosyal medyanın yaygınlaşmasıyla birlikte gelişen bireyin ifade özgürlüğü alanı, iletişim süreçlerini de kökünden değiştirmiştir. Özgürlük alanları genişledikçe bundan rahatsızlık duyan bir kesimin de aynı hızla ortaya çıkması tarihte sık sık karşılaşılan bir desen olarak belirmiştir. İnternet'in oluşturduğu bu özgürlük alanının da sansüre uğraması bu sebeple çok yadırganacak bir durum değildir. Ancak İnternet sansürüyle ilgili durumun vahameti de gözden kaçırılmaması gereken bir konudur.

Otosansürün geleneksel medya ve sanatçılardan ayrılarak bireyin gündelik yaşamının bir sorunu haline gelmesi, sosyal medyanın karşı karşıya olduğu gözetim haliyle doğrudan ilişkilendirilebilmektedir. Bir örnek olarak incelendiğindeyse Facebook, otosansürün uygulanması için gerekli uygun yapıyı bünyesinde barındirmaktadır.

Yapılan bu araştırma sonucunda kullanıcıların Facebook kullanım alışkanlıkları incelenmiş, Facebook'a güven düzeyleri ortaya konmuş ve otosansür davranışlarıyla ilgili bilgi toplanmıştır. Facebook'la ilgili genel verilere ek olarak, 
kullanıcıların Facebook kullanımlarının yoğun olduğu ve bu yoğunluğun mobil cihaz kullanımıyla birlikte artış gösterdiği saptanmıştır. Facebook, kullanıcıların günlük rutini içinde kalıcı bir yer edinen bir yapıya dönüşmeye başlamıştır. Bireylerarası iletişimde sağladığı işlev ile kişilere kendi kimliklerini sunma şansı vermesi açısından Facebook, talep gören bir sosyal paylaşım ağı olarak gösterilebilmektedir.

Kişilerin kimlik sunumlarıyla ilgili en önemli konu yanlış anlaşılma korkusu olarak öne çıkmaktadır. Verdikleri yanıtlara göre katılımcılar, arkadaşları tarafından istemedikleri şekilde algılanmaktan çekinmektedirler. Bu durum Goffman'ın benliğin sunumu konusunda söyledikleriyle tamamen örtüşmektedir. Sleeper vd.'nin de (2013) araştırmalarında ortaya koyduğu gibi kimlik sunumu konusu ciddi bir otosansür sebebi olarak kendini göstermektedir.

Otosansüre eğilim ölçeğinde çevrimiçi anket sonuçlarına bakıldığında sonuçların birbirine yakın oranlarda farklılaştığı görülmektedir. Bu konuyla ilgili olarak insanların bazı şeylerden çekinerek kendilerini kısıtladıklarını belirtmeyi tercih etmedikleri de düşünülebilir. Aynı zamanda suskunluk sarmalı etkisi, gözetim korkusu ve kimlik sunumuyla ilgili çekinceler otosansürün birbirinden farklı biçimlerde ortaya çıkmasına neden olmaktadır. Yarı yapılandırılmış görüşme verileri incelendiğinde gözetimle ilgili korkular ve kimlik sunumu kaygılarının çok daha yaygın olduğu görülmüştür.

Bununla birlikte Facebook, geniş sayıda kullanıcı tarafından güvenilir bulunmamaktadır. Kullanıcılar kişisel bilgi ve fotoğraflarının yeterince korunmadığını düşünmekle birlikte, söz konusu verilerin üçüncü şahıslarla paylaşıldığını da düşünmektedir. Ancak bu durumun Facebook’un piyasadaki yerini sarsacak bir etki yaratmadığı söylenebilir. Kullanıcıların bu durumu adeta kabullendikleri ve otosansürü içselleştirerek yaşadıkları söylenebilir.

$\mathrm{Bu}$ sonuçlara bakıldığında gözetime uyum sağlayarak alışkanlıklarımızı devam ettirdiğimiz sonucu ortaya çıkmaktadır. Kullanıcılar genellikle olumsuzluklarla savaşmak yerine onları kendi amacına uygun bir şekilde şekillendirmeye daha meyillidir. Tüm bunların sonucunda, birçok İnternet kullanıcısının içselleştirme yoluyla farkında olmadan otosansür uyguladığını 
söylemek mümkündür. Otosansürün her zaman üzerine düşünülerek gerçekleştirilen bilinçli bir eylem değil, bir zorunluluk olarak da ortaya çıktığını söylemek yanlış olmayacaktır. Ancak farkına varmadan yapılan otosansür, otosansürün ortaya çıkmasına sebep olan faktörleri çok daha fazla besleyen bir durumdur. Bu faktörlerle ilgili harekete geçilmediği sürece otosansür çok daha geniş bir kitle tarafından içselleştirilecek ve ifade özgürlüğü alanı git gide daralmaya devam edecektir.

\section{KAYNAKÇA}

5651 SAYILI KANUN (2007). “İnternet Ortamında Yapılan Yayınların Düzenlenmesi ve Bu Yayınlar Yoluyla İşlenmen Suçlarla Mücadele Edilmesi Hakkında Kanun”, http://www.tbmm.gov.tr/kanunlar/k5651.html, Erişim tarihi: 01.02.2015.

AB İLERLEME RAPORU (2012). http://t24.com.tr/media/editorials/files/2012_ ilerleme_raporu_tr.pdf, Erişim tarihi: 08.10.2014.

COOK, Philip ve HEIMANN, Conrad (2010). Censorship and Two Types of SelfCensorship. http://papers.ssrn.com/sol3/papers.cfm?abstract_id=1575662, Erişim tarihi: 11.11 .2014 .

CRESWELL, John. W. (2005). Educational Research. Planning, Conducting, and Evaluating Quantitative and Qualitative Research, ABD: Pearson Educattion. ERDOĞAN, İrfan ve ALEMDAR, Korkmaz (2010). Öteki Kuram, Ankara: Erk Yayınları.

FILAK, Vincent; REINARDY Scott; MAKSL, Adam (2009). "Expanding and Validating Applications of the Willingness to Self-Censor Scale: SelfCensorship and Media Advisers' Comfort Level with Controversial Topics”, Journalism \& Mass Communication Quarterly, 82, p.368-382 http://jmq.sagepub.com/content/86/2/368, Erişim tarihi: 03.11.2014.

GOFFMAN, Erving (2009). Günlük Yaşamda Benliğin Sunumu, (Çev: B. Cezar), İstanbul: Metis Yayınları.

GÖREN, Zafer (2014). “İnternet Özgürlüğünün Koruma Alanı ve Sınırları”, İstanbul Ticaret Üniversitesi Sosyal Bilimler Dergisi, $13 \quad$ (26), 9-25 
http://acikerisim.iticu.edu.tr:8080/xmlui/bitstream/handle/11467/899/M00580 .pdf? sequence=1\&isAllowed=y, Erişim tarihi: 20.01.2015.

HAYES, Andrew F.; GLYNN, Carroll.; J. SHANAHAN, James (2005a). "Willingness to Self-Censor: A Construct and Measurement Tool For Public Opinion Research", International Journal of Public Opinion Research, 17 (3), s.298-323. http://search.ebscohost.com/login.aspx?direct=true $\& d b=a 9 h \& A N=$ 18394524\&lang=tr\&site=ehost-live, Erişim tarihi: 03.11.2014.

HAYES, Andrew. F.; GLYNN, Carroll.; J. SHANAHAN, James (2005b). "Validating the Willingness to Self-Censor Scale: Individual Differences in The Effect of the Climate of Opinion on Opinion Expression”, International Journal of Public Opinion Research, 17 (4), p.443-454, http://search.ebscohost.com/login. aspx $?$ direct $=$ true $\& d b=a 9 h \& A N=19253616 \&$ lang $=$ tr $\&$ site=ehost-live, Erişim tarihi: 03.11.2014.

KALAMAN, Sefer (2011). İnternette özel hayatın gizliliğinin ihlal edilmesi: Facebook, Yayınlanmamış Yüksek Lisans Tezi, Konya: Selçuk Üniversitesi.

KEMP, Simon. (2015). Digital, Social \& Mobile in 2015, http://wearesocial.com/uk/special-reports/digital-social-mobile-worldwide2015, Erişim tarihi: 01.02.2015.

KÖSE, Güven ve ÖZEN, Kerem (2010). “İnternet’te Sansür Üzerine Bir Değerlendirme", http://www.bby.hacettepe.edu.tr/e-bulten/dosyalar/file/kose_ ozen_by2010.pdf, Erişim tarihi: 11.11.2014.

SHIELD, Patricia M. ve RANGARJAN, Nandhini.(2013). A Playbook for Research Methods: Integrating Conceptual Frameworks and Project Management, ABD: New Forums Press.

SLEEPER, Manya; BALEBAKO, Rebecca; DAS, Sauvic; McCONAHY, Amber Lynn; WIESE, Jason; CRANOR, Lorrie Faith (2013), “The post that wasn't: exploring self-censorship on Facebook", http://dl.acm.org/citation.cfm ?id=2441865, Erişim tarihi: 09.09.2014. 
TOPRAK, Ali; YILDIRIM, Ayşenur; AYGÜL, Eser; BİNARK, Mutlu.; BÖREKÇİ, Senem; ÇOMU, Tuğrul (2009). Toplumsal Paylaşım Ağı Facebook: “Görülüyorum Öyleyse Varım!”, İstanbul: Kalkedon Yayınları.

TÜFEKÇİ, Zeynep (2008). "Can you see me now? Audience and disclosure regulation in online social network sites”, Bulletin of Science, Technology \& Society, 28 (1), 20-36.

UÇKAN, Özgür (2009), “Türkiye'de İnternet Sansürünün Kısa Tarihi... Ve Mümkün Geleceği!", http://sansuresansur.blogspot.com.tr/2009/09/turkiyede-İnternetsansurunun-ksa.html, Erişim tarihi: 20.01.2015.

YILDIRIM, Ali ve ŞİMŞEK, Hasan (2013). Sosyal Bilimlerde Nitel Araştırma Yöntemleri, (9. Baskı), Ankara: Seçkin Yayıncılık. 